\title{
Perceptions of Tourism sector campaigns- Hidden Veracities
}

\author{
Dr. Thresiamma Varghese \\ Assistant Professor, \\ Sohar University, Oman
}

Ms. Hiba Abduallah Said

Students, Faculty of Business, Sohar University, Sultanate of Oman

\author{
Ms. Maryam Khalifa Al Bloshi \\ Students, Faculty of Business, \\ Sohar University, Sultanate of Oman
}

\author{
Ms. Sohailah Khalifa Al Bloshi \\ Students, Faculty of Business, \\ Sohar University, Sultanate of Oman
}

\author{
Ms. Reem Mohammed Al Karosi \\ Students, Faculty of Business, \\ Sohar University, Sultanate of Oman
}

\begin{abstract}
The Ministry of Tourism is the government agency responsible for the tourism sector in the Sultanate of Oman. The main mission of the Ministry of Tourism is to promote Oman's tourism sector regionally and globally by providing all the tourist information about its amazing locations and the heritage of the original Arabs. Natural tourist sites in Oman are mainly a source of attraction to tourists from around the world. This research aims to look at the tourism sector in Oman and to identify the strategies and techniques used by the Sultanate to promote tourism in Oman. We have collected data using primary sources through interviews with relevant authorities at the Ministry of Tourism, which have the authority to develop tourism sector in Oman. Moreover, we have collected information from tourist and various other sources such as websites, magazines, newspapers etc. One of the main finding of this study is that many respondents believes now-a -days tourism sector provides job opportunities to Omanis and moreover the tourism development is part of diversification strategy of Oman to enhance the income of the country.
\end{abstract}

Keywords: Tourism development, Sustainable development, Politics, Social environment, Infrastructure, Travel.

\section{INTRODUCTION}

Promoting tourism means 'stimulating tourism sales' through information distribution. This means trying to encourage actual and potential customers to travel. Good promotion is in other sense a moral communication. The government of Oman has come up with many tourism promotion plans through Ministry of Tourism which in turn accelerate the growth in the sector .Moreover, the Ministry has prepared long run tourism strategies covering the period of 20162040 .Since it has been enacted, there has been much improvement in the tourism sector and it is intended that the strategy will contribute to an increase of job opportunities until 2040, 
plan to reach more than 500 thousand jobs, and the expected volume of investments during 2016 to 2040 is R0 19 billion. The sector is looking forward at least $12 \%$ of investments from the public sector as well. In addition, it is expected that the GDP of Oman would increase by a minimum of $6 \%$ by 2040 through the development of tourism sector. Apparently, tourism sector would contribute to the development of local economy through the enhancement of small and medium enterprises .The Ministry expects an addition of 1200 enterprises by 2040 . (Ministry of Tourism Data bank).

The tourism strategies aim to enhance the Sultanate's tourism position globally and make it a global destination for hospitality. During the first quarter of 2018, 41 hotels and 64 hotel apartments were approved with an average of more than 5,000 rooms. In ten years from now, global tourism will become the main economic engine of global employment by more than $11 \%$ and will contribute to global GDP by more than 9\%. The strategy aims at improving the contribution of tourism sector on the prosperity of Sultanate of Oman by creating a competitive advantage. Attention has been paid to inviting visitors who are expected to stay longer and spend money in domestic market, thereby realizing greater benefits without leaving negative impacts on culture and the environment. The Ministry of Tourism is keen to keep pace with the rapid changes and the great transformation in electronic services. In this regard, the Ministry launched an electronic system to serve investors and those who are interested in the tourism sector.

At this juncture, there would be always nice to have a look on the tourism sector, and as of now, we have been informed that there are many factors, social and cultural, hinders the development of tourism in Oman. The reviews of literature says us that there are many concrete areas to be involved or some changes has need to be done to tourism sector. The main objective behind this study is to look at the promotional areas of tourism development. Moreover, good Infrastructure plays a key role in attracting tourists in any country. It is always appreciable to rethink of frameworks, laws and regulations of the tourism sector and if any changes or additions required to enhance the efficiency of the sector in Oman as while it is looking forward to have more diversification in the economy because of the depletion of global oil prices. Emphasis should be placed on the diversification of tourism projects and the integration and promotion of local tourism. Current study has gone through a qualitative approach, as people perception is the main way to reach the people's subjective needs and aspirations. This study will add value to the tourism literature in Oman, where tourism has become an important sector contributing to the development of the Oman economy. This research paper reflect on the online and offline promotional strategies/techniques used by the Sultanate of Oman to attract local tourists/foreign tourists and to oversee how effective are the strategies/techniques in attracting local tourists. Since, tourism sector is one of the crucial area where Oman is looking for its future as it is strategically important to create job opportunities for youth, this study sure will add value to impart tourism awareness among officials who are always thinking to develop Oman's tourism arena.

\section{RESEARCH METHODOLOGY}

One of the purpose of this study is to determine the factors that affect, through consumer perceptions, the development of the tourism sector in Oman. In addition, the aim of this research is to look at Oman's tourism development strategies -mainly promotional strategies. It is known that the social and cultural factors have an effect on tourism development in Oman. Infrastructure also play a key role in the attraction of tourist locations. We feel it is high time to change the frameworks, laws and regulations of the tourism sector in order to enhance the efficiency of the sector and to manage and operate tourism related small enterprises. Emphasis should be placed on diversification of tourism projects and integration and promotion of 
domestic tourism. The main objective of this research is to search for viewpoints of tourism facilitators and tourists in Oman, which may help to implement proper criteria for developing sustainable tourism, regional balance in tourism, community participation in the development of local tourism, enhancing the quality and competitiveness of tourism services and developing of small enterprises operating in the tourism sector.

In this study, involving strategies used for tourism promotion in Oman, we have looked at the strategies/techniques used by the Sultanate of Oman in promoting tourism sector. Data has collected through interview from employees of tourism industry and from tourists. We chose random sample mainly focused on experienced employees and tourists. We have interviewed about 20 employees from Ministry of tourism, private travel agencies, airlines, hotels and 50 tourists from different tourist locations in Oman. In addition, we have used Ministry of tourism websites for further information.

\section{LITERATURE REVIEW}

Parashar et al., (2013) have done a study on 'Contribution of media to promote the Tourism in India '. The data collected from International tourists in India. The main findings of the study are, Tourism is a very large industry in India and contributed to domestic product enhance employment as well. In addition, over the years the proportion of tourists' visits in India has grown because of media promotion. Movahed et al., (2005) did a research on' Promoting Tourism Industry as a Suitable Way for Development'. The data for the study was collected from visitors that were recorded in Shiraz. The main findings of the study are Tourism Industry remain the main sector which has led to major development to Shiraz City. Another study by Okech et al., (2014) on the 'Impact promoting the Spa Tourism Industry in Kenya'. The data collected through an internet survey questionnaire. One of the findings of the study is that tourism sector in Kenya has led to a high impact on country's growth and development. Dawson et al., (2011) had done a study on 'Canadian Tourism Promotion and the celebration of Mass Culture'. The main findings of the study are mass tourism was integrated into American public debates and tourism is a tool for making a more harmonious society. A study was conducted by Kumar et al, (2015) on 'Contribution of Public and Private Sector in Promoting State Tourism in India. The main finding of the study are through various journals, studies, websites and publications of Ministry of Tourism, Government of India and Department of Tourism, Government of Gujarat could help major changes in the tourism arena..

Aulia et al., (2015) studied on 'Opportunities of Tourism in Sultanate of Oman. The main findings of the study urges a special attention to develop strategies for the development of tourism to eliminate all impediments to tourism sector and the tourists. Al Balushi et al., (2012)' Review of awareness and views on branding Oman as a nation for tourists '.The study suggested that it is the high time to focus on the holistic view of tourism sector through the use of social media and international exhibitions. Salehi et al., (2014) studied on 'Tourism advertisement Management and effective tools in tourism industry 'The study agreed that are advertisements and multi-language speaking tourist guides would be a great help for tourism promotion. Martin et al., (2005), conducted a study Oman's tourism industry. He found that the number of tourists in the Gulf countries increase by 5.5\%, equivalent to the number of visitors to Southeast Asia and North Europe during the years 2000 -2005. Furrer et al., (2016) have done a research on Social Media and Promotion of Tourist Destinations and country images. The main findings of the study are there is a good link between the visitors' positive image on countries, while they visit a country, and the image, which has been promoted through media, is important for any future connections. Hudson et al., (2006), conducted a study on 'Promoting Destinations via Film Tourism' suggested that viewing sites in a film is an effective and quick way to increase the number of tourists. According to Rajiha et al., (2010) 
'Promoting Tourism in Abu Dhabi using Social Media' agreed that updating pages in social networking sites, activating them, branding and promoting identity, promoting the development of physical activities and historical resources would help tourism promotion.

A study conducted by Sambhanthan. (2012) on 'Strategic Advantage in Web Tourism Promotion: An e-Commerce Strategy for Developing Countries'. The main findings of the study are effective use of information technology is successful in tourism promotion in terms of quality information and the ease of use. Another study conducted by Chheang et al., (1990) Tourism Development in Cambodia: Opportunities for Japnese Companies' found that the development of strategies like promotion of tourism by the government and the private sector and the advance of infrastructure would increase the number of tourists significantly.

\section{ANALYSIS AND DISCUSSION}

We have conducted tourist interviews and interviewed respondents from Ministry of Tourism/private travel agencies, airlines and hotels in Oman. We interviewed tourists from hotels like Radisson Blue Hotel, Sohar Beach Hotel, and Mercure Hotel and from Muscat International Airport as will. Session below involves different interview questions and the respondent's opinions.

\section{What is tourism? Why is it important for economic development?}

Almost everyone agreed on one meaning of tourism that, 'tourism is the movement of people from one place to another with the aim of evolving in several activities, including entertainment and practice of religious rites'. Mr. Salem is on the view that promotion of tourism will provide income through job opportunities. According to Ms. Zineb tourism, internal as well as external, is people's leisure activity that could enhance economic development. There are many components of tourism like sports tourism, cultural tourism and health tourism, she added. According to Mr. Omar, tourism sector sure would contributes to the economic development and it helps in increasing the per capita income of the people. Mr. Ali added that tourism is important to the development of any country, which would play an important role in increasing foreign investment, which would makes it easier for the country to facilitate trade. Mr. Ahmad said that the tourism sector might contributes effectively to support the State tax income. According to Ms. Aisha, tourism sector has backed to the development of many countries and the same is the situation in Oman as well through the surge of Gross Domestic Product.

\section{To what extent does the tourism sector affect the development of Oman economy and its image?}

Many respondents believe that tourism sector affects the development of the Oman economy and its image significantly. Mr. Khaled said 'tourism sector could be a very positive factor for economic development in Oman and could bring a true picture Oman'. Mr. Salem's view is that this sector should be first one to advance in order to enhance the economy. $45 \%$ of the respondents agreed on the importance tourism sector in the development of the economy. Mr. Mohammed added that the tourism sector contributes to provide employment opportunities for Omani youth. Ms. Reem said that tourism is helping to improve the country's economy through foreign investment. Mr. Munther said the tourism sector in Oman has grown further since last five years. Mr. Ali added that when the number of tourists increase to a local destination, the accompanying business activities are activated and this would contribute to the economy. According to Mr.Salim,'tourism has become increasingly important as an industry and a profession as we can see that Oman's Universities, colleges and technical institutes have a specialization in tourism in their curriculum as well. Ms. Hajar said that tourism is an important source of foreign currency acquisition and that the tourist spends on 
goods and services from these currencies. According to Mohammed, Tourists are creating demand for goods and services in Oman economy. Mr. Khalid said that tourism aims to achieve sustainable development and contribute and appreciate Oman's cultural heritage, the preservation of values, traditions, customs and contribute to the understanding of inter country relations and tolerance.

\section{What factors are affecting the tourism sector of Oman?}

Here too there are many different answers, but some are agreed on few common factors, for example, Mr. Ahmad alleged that the factors influencing the tourism sector in Oman maybe the issues such as security, ethics of people, transport and communications. Mr. Omar added that the factors influencing the tourism sector could be the environmental factors that the Sultanate of Oman have though its strategic geographical position, its weather conditions, the provision of tourist services, and the maintenance of public facilities. Mr.Yusif agreed that, Oman has a major infrastructure for tourism investment as well as transportation and banks that can help to revitalize the tourism sector in Oman. Ms. Eman says one of the important favoring factor is the political stability of Oman. Further, Oman is rated as 'zero' in the world terrorism index in 2018.

The small percentage $(10 \%)$ of the respondents believed that Oman is lacking services like streets lights in remote areas or distant mountainous areas and public toilet facilities. Mr. Ali believed that tourism is also heavily affected by the economic situation of Oman after since the oil prices issues globally.

\section{Does the environment and society could affect the tourism sector in Oman?}

$46 \%$ of respondents are agreed that the environment and society would affect the tourism sector in Oman. .Ms. Amal said, "Environment and society can affect tourism through attractive climate, landscapes, the generosity of the Omanis and their kind gesture. The clean environment is reflected in the extent to which a society maintains its nature. The community must deal with the tourist in a way that makes them feel secure, she added. Mr. Ali has agreed that the environment and society have a great impact on tourism arena as the society reflects the values of individuals and the ethics of the State.

\section{What are the online promotional strategies / techniques used by the Sultanate of Oman to attract domestic and foreign tourists?}

Because of technological development around the world, the Ministry of Tourism of Oman has used modern ways and means to promote tourist to visit Oman mainly in Oman's archeological sites. Mr. Ahmed, Mohammed agreed that the ministry website and the television are the important tools to promote the tourism activities in a timely manner. On the other hand, Ms. Maryam Aisha, Fatima and Ms.Ahlam said that Radio, TV channel advertisements, online reports, videos are a great help too. Further, Oman government could use several strategies, techniques and links that can contain photos of important tourist areas in Oman. Mr. Faisal opined that ministry of tourism should increase the activation of the ministry website through more tourism information, photos, videos, summer presentations, prizes and mobile apps to attract more tourists.

\section{What are the offline strategies / promotional techniques used by the Sultanate of Oman to attract domestic and foreign tourists?}

Few answers are differed, but most of the answers were very close in this head. For example, we start with Mr. Ahmed, who said that there are two offline methods use to encourage tourism in Oman such as images and magazines. For Mr. Salem, the view is different and he said the strategies are using are like school trips to natural places and even camping to do a 
good promotion as school children can be good promotor for tourism. Ms. Hiba says," We can encourage tourism by being educating tourist guides which would help them to select the right tourist location in Oman". Mr. Salem agreed with Ms. Mozah on the importance of government publications as tourism promotion devices. According to Mr. Nasser local and international newspapers and magazines, exhibitions and international events would be great help for tourism promotion. Majority of the respondents are agreed on the use of new papers and leaflets. Ms. Amara think that business trips would be helpful for tourism promotional activities. Mr. Hamad believed that many other strategies also could work, such as use of region's indigenous people/locals as tourist guides. Mr. Mohammed believes that public lectures and workshops would also help in the promotional activities.

\section{How effective are the strategies / methods of attracting local /foreign tourists?}

People's opinions were different on whether the strategies and techniques have a clear impact on tourism promotion or not in the desired form. We start with Mr. Said, who believes that these technologies have an effective role in increasing the number of tourists. Ms. Aisha said that tourism sector of Oman has growing more than in previous years. Mr. Mahmoud also said that the strategies are effective as the people around the world are getting informed on Oman's natural beauty. Ms. Khadija said "through techniques/strategies only we have increased the number of tourists" One of the officials of the Ministry of Tourism believed on promotion strategies but he looking for more promotional activities to enhance the sector. Ms. Hiba says" the techniques being used are good but we should look for more amenities like good number of hotels and malls with entertainment facilities in order to promote tourism.11\% of respondents only think that the strategies have been effective and have increased the number of tourists significantly. Mr. Salem said that through tourism promotion we could see more tourists from different countries with diverse nature /ethnicity in Sultanate of Oman. Ms. Maryam also expressed her opinion that the tourism promotion strategies have contributed to raise the level of income and increase the value of the country. Ms. Anoud agreed that participation in international exhibitions and conferences and offers and invitation to international companies to visit Sultanate could enhance tourism arena of Oman. Mr. Khalil feels that there is high growth in tourism activities in recent years and has increased the volume of tourist and the foreign investment in Oman.

\section{What are your suggestions for developing tourism sector in 0man?}

According to Mr. Salem, the government should work with local people to develop the tourism sector in Oman. According to Ms. Hanna "Oman must develop tourism through communication sites and provide the best services to tourists". Mr. Yousef agreed with Hanaa that tourist places need a holistic development in Oman. Ms. Aisha had a different view, suggesting that more television programs should be aimed to impart information. Mr. Sultan think that Oman Air should be strengthened, provide with tourist information, and authenticated leaflets. Ms. Al-kwther said that events that are more traditional should be held to promote tourism framework. Mr. Nasser said that infrastructure, transportation, communications in the Sultanate should be developed and more promotional events should be held in different countries. Mr. Ali also suggested that easy visa process should facilitate both inward and outward tourism. According to Mr. Ahmed increase in the number of different shopping places of Omani and international brands would help tourism promotion. There should be a new place for entertainment in different ways, good resorts and entertainment centers, Ms. Fatima said. Ms.Lathifa suggested the establishment of websites and electronic services on the most visited places and the demodulation of tourist sites and servers. $20 \%$ of respondents are on the same opinion that Omani youth should be advised to participate in domestic tourism, raise awareness of the importance of the future of Oman, media focus on tourist areas, improve public services, build water parks, recreational parks and festivals. Ms. Noura proposed the 
development and maintenance of tourist facilities on a regular basis, providing services and facilities for both domestic and foreign tourists. Ms.Noora think that offering a variety of services to local and foreign tourists and the help of investors and international volunteers can be good help. Attractive and good maintained sites with toilet facilities would be great help to promote tourism in Oman In addition, Mr. Ali suggested that providing services such as increasing the number of restaurants in remote places, provision of lighting facilities in mountain areas and the increase the number of car parking slots in the markets would help. Mr. Anas suggested that increase the number of television programs in order to acquaint people with the history of Oman/ tourist places would be help helpful for tourism promotion. Mr. Hassan proposed more parks and animal zoos that can attracts tourists. He suggested that regular maintenance of public facilities, attention to infrastructure development would be a good gesture to improve tourism sector.

\section{Do you think that the tourism promotional strategies are proper in Oman?}

$30 \%$ of the respondents think that strategies are effective and $20 \%$ of them are dissatisfied with those strategies. Mr. Salem said that the strategies used by the Sultanate of Oman are limited to specific sites and consumers. Ms. Marwa is satisfied with the tourism promotion in Oman. Ms. Maryam think that the promotional strategies are not appropriate. Mr. Mohammed opines that there is a great way to move towards promotional plans on Oman's heritage, traditions and its glorious history. Mr. Abdullah think that promotional channels are not appropriate to meet the goal of attracting more tourists. Mr. Khalid think that the promotional tools should be up to date with the global needs. Ms. Reem said that we do not use modern tools and new ideas to promote. Mr. Hussein added that there is an increase in visitors in the region Salalah but other areas in Oman are neglected. Mr. Ahmed said we needs a range of modern tourist services that can improve the tourist arena of Oman.

\section{Any suggestion for improving tourism promotion in Oman?}

In this direction, $10 \%$ of the respondents do not have any proposal to develop tourism. While $20 \%$ of respondents have come with proposals for development tourism sector in the Sultanate of Oman. First, Mr. Khalid said that sector should need more strategies that are effective while Mr. Munther suggested that social media should be used to strengthen the tourism sector in the Sultanate. Ms. Mazneh suggested that the tourism sector should cooperate with large and well-known international companies. Ms. Hager agreed with Mr. Munther's suggestion that more emphasis should be placed on the use of modern means of promoting the sector. Mr. Anas suggested that television programs should be used to impart diverse information to people and countries. Ms. Aisha said that the government needs to improve its services and strengthen infrastructure while Mr. Majid pointed out the importance of Oman to keep pace with the tourism sector of other countries mainly GCC Countries. $20 \%$ of Tourism Ministry officials proposed to set up many international hotels to increase leisure and to be more open to the outside world. Mr. Ahmed also suggest with Mr. Salim and Ms. Reem that tourism sector be strengthened and made more open. Mr. Hussein suggested that the sector should establish tourist information offices for each region in the Sultanate.

\section{What do you think of the future of tourism sector in Oman?}

In this question, $40 \%$ of the respondents believed that the future of the Omani tourism sector would be prosperous and progressive in the coming years. First, Mr. Mahmoud points out that people and the government should coordinate each other to improve the tourism sector. Mr. Khalid explained that the tourism sector would sure play an important and prominent role in attracting tourists from around the world. Mr. Youssef said that government support for this sector should be intensified to be a distinct sector. In addition, he stressed the need to develop new Government laws and strategies for tourism promotion. Ms. Reem is confident that the 
Sultanate of Oman would be a great tourist destination in the coming future. Mr. Rashid pointed out that the Sultanate of Oman will as the most important Gulf tourist country. Ms. Eman said that the tourism sector would be the sector that Oman will depend on raising the national economy after oil and contribute to increase the income of individuals. She added that the process of obtaining visas should be facilitated to ensure a more privileged and easy tourism. Mr. Marwan said that the future of the tourism sector will be increasing continuously and that will grow rapidly and significantly if Oman takes the people's proposals and takes the right measures. Mr. Salem said that the sector would be more developed if we update the current means of promotion. Mr. Yousef believes that Oman has many tourism features that would explore in the near future. $10 \%$ of respondent are not sure or positive about the future of the tourism sector in Oman.

\section{How tourism ministry support tourism sector in Oman?}

The government recognizes the importance of the tourism sector in the future, as it started to take care of this sector and develop it. In the past, it has signed many agreements and laid down the basics of many tourism projects that would make the Sultanate of Oman a tourist interface with advanced international standards. Oman officials participate in the Arabian Travel Market 2016, which was held in Dubai, which attracted the pioneers of the tourism industry at the local and international levels. The Sultanate of Oman also involved in several tourist projects like 'Rotana Shalala', "Al Jabal Al Akhdar etc. Oman also developed the infrastructure of tourist areas like good quality restaurants, hotels and convenient and modern transportation Mrs. Mariam from Ministry of Tourism, said that the government would work on the waterfront project of the Sultan Qaboos commercial port to a world tourist destination, which includes commercial and residential areas, hotels, as well as a marina for yachts and large cruise ships. The government will also implement the "Diyar Ras Al Hadd" project, which will be an integrated tourism project, which includes hotels, malls, heritage facilities, residential villas and water parks. Apart from that, an agreement will be signed for the City Walk Muscat project, which is a shopping mall with a beachfront view, which would include many shops, restaurants, hotels and movie theaters at a cost of 80 million Omani riyals.

\section{CONCLUSION AND RECOMMENDATIONS}

Ministry of Tourism officials revealed that, Oman's tourism strategy targets investment of 19 billion Omani Rials and 500,000 job opportunities for Omani youth and will attracts 5.3 million tourists by 2040. These strategies would attract foreign investment as they have opened the way for foreign investors to open projects and companies in Oman. Oman's strategy is to strengthen the Sultanate's position globally and to promote economic diversification through tourism sector enhancement. Our research agreed that advanced technology globally has contributed significantly to the tourism sector in Oman. The Ministry websites including Instagram pictures, information and video on the tourist sites would be helpful. Most of the tourists agreed that websites are playing an important role in promoting tourism compared to the previous years. Moreover, the allocation of some television programs about Oman tourism sector would be a great help.

In addition, the government has made great efforts to attract many tourists through is public promotion in newspapers and magazines. Moreover, many hotels and restaurants have also been developed as per the wishes of the tourists. Government is alert in providing advanced transportation and security in most important natural and tourist attractions in Oman. Furthermore, the Sultanate also has participated in several international exhibitions in order to promote Omani cultural tourism as well as holding workshops to develop Omani youth to enter in to tourism sector and gain knowledge and experience. Over the past years, the government has established parks, resorts and shopping malls with high standards and high 
quality, in accordance with the international standards corresponding to summer and discounts offers.

It is implicit that Ministry of Tourism seeks to develop the tourism sector in cooperation with the concerned authorities and local communities. The peace and security resulting from political stability is one of the most important factors that attract tourist towards Oman. The Ministry also held exhibitions in various countries highlighting the most important tourist and archaeological sites in the Sultanate, as well as providing convenient and modern means of transport for the tourists. The government has also allocated about \$ 51 million to launch and develop business through the establishment of several shopping centers, resorts, gardens and restaurants.

Foreign tourists also expressed their appreciation towards the generosity of the Ministry of Tourism in the Sultanate of Oman, where it has made many agreements and commitments to attract more than 5 million foreign tourists through the facilitation of traffic procedures and registration at airports since 2005 . Where the number of foreign tourists were about 10,700 during the period from 2005 to 2007, and doubled the number of tourists during the period from the year 2008 to 2009 to 22,000 foreign tourists. The Ministry has also operated dozens of flights to the Arabian Gulf, the Middle East and Europe, and has built several tourism facilities in accordance with international standards for the guest convenience, such as the establishment of several museums, hotels and facilities worth of OMR 238 million so far. It also provided modern means of communication and information to tourists through agreement with the National Channel of Oman broadcast as a promotional program, which explore the most important tourist attractions of Omani heritage and natural/ modern architecture. The Ministry also restored the port of Sultan Qaboos to as a port for the transportation of goods, which would led to an increase of the number of tourists by $24 \%$ in the year 2018. Moreover, the generosity of Omani society and their good dealings with foreign tourists would be a great help.

Apparently, Tourism is of great importance and play a prominent role in the growth and development of the world economy, where many countries are largely depend on the tourism sector as an income-generating sector. Likewise, Oman also is looking forward to tourism sector to diversify the economy while there is a major threat is there in the oil sector. Furthermore, tourism sector can generate more employment openings as well. Oman. Moreover, it helps businesspersons to do a lot of investment that can appeal further foreign investment.

We have concluded that the tourism sector would be a source of local income and the growth of this sector would contribute to the GDP of the Sultanate. The strategies are aim to strengthen the Sultanate's position in tourism globally. Our study agreed that, ten years from now, Oman's tourism sector becomes the main economic arena of employment generation globally -say, more than $11 \%$ and would contribute to the world GDP by more than $9 \%$ in the coming years. The future of tourism in Sultanate of Oman would be remarkable.

\section{Recommendations:}

In order to overcome the challenges and maximize the benefits to develop the tourism arena, the following recommendations would be helpful.

1. Develop more strategies in the Ministry of Tourism to develop the tourism sector in line with the aspirations of various tourists.

2. Expand and diversify offers to improve the yield and social value. 
3. The local population should be aware of the government's efforts to protect the environment and explain its advantages in developing the tourism sector.

4. The Government should make a strong effort to protect Oman environments and wildlife.

5. The Ministry of Tourism should intensify awareness among the local population because they are more able to accept and agree with most tourist activities.

6. Must add more restaurants, cafes and public toilets in all areas of the Sultanate of Oman.

7. Exploit natural tourism resources and historical and cultural studied to realize the benefits of contemporary Omani society.

8. Maintain the attractions of the various marketing centers, popular entertainment sites to meet the needs of tourists in Oman.

9. Raise the percentage of Omani nationals within the total hospitality sector labor force, through the development of their skills in the field.

10. Increase awareness in the development of domestic tourism and the progress commensurate with different types of tourists.

11. Local institutions and members of society should benefit from the main economic benefits.

12. Strengthen the link between the government and the private players in tourism sector.

13. Trigger the tourist movement in the Sultanate of Oman as a prestigious tourist center through attract tourists in Arabian Gulf region and the world in general.

14. Understand the diversity of tourism groups and their needs.

15. Generate national capacity in the field of tourism, environment and natural resource management to serve the goals of sustainable development that the Sultanate is seeking to achieve in various arenas.

16. Promote the role and contribution of the private sector within the framework of the National Tourism Development Plan.

\section{References}

Aulia S,(2015) Opportunities of Tourism in Sultanate of Oman, International Journal of Research in Tourism and Hospitality (IJRTH) Volume 1, Issue 2, 2015, PP 13-15 ISSN 2455-0043 www.arcjournals.org

Al Balushi et al., (2012)' Review of awareness and views on branding Oman as a nation for tourists ', www. ijbtsjournal.com/images/main 1366796751/0112-maha.pdf

Bradley Ben, and, I. Little, (2016), Introduction: Canadian Tourism History, Histoire sociale / Social History, vol. XLIX, no 99 (Juin / June 2016)

Chheang. V (1990), Tourism development in Cambodia: An analysis of opportunities for Japanese,www.ide.go.jp/Library/English/Public/Download/Brc/Pdf/02-ch1-pdf

Dawson. M (2004), Selling British Colombia: Tourism and Consumer culture, 1890 -1970.Vancouvr: University of British Columbia Press, 2004.

Emaad Muhanna (2006). Sustainable Tourism Development and Environmental Management for Developing Countries. Problems and Perspectives in Management, Problems and Perspectives in Management, 4/2

Furrer , 0 and Kuric,N,(2016) ,Social Media and Promotion of Tourist Destinations with Negative Country Image,, University of Fribourg, Switzerland Faculty of Economics and Social Sciences Department of Economics Studies: Master of Arts in European Business Master Thesis.

Hudson, S (2006) Promoting Destinations via Film Tourism: An Empirical Identification of Supporting Marketing Initiatives, Journal of Travel Research 44(4):387

Parashar et al., (2013), 'Contribution of media to promote the Tourism in India', International Journal of Education, Issue October 2013, Vol. 1 ISSN (Online):2347-4343, Web Presence: http://ijoe.vidyapublications.com

Movahed .K, (2005) Promoting Tourism Industry as a Suitable Way for Development of Shiraz City, 41st ISoCaRP Congress 2005

Okech et al. (2014) Promoting the Spa Tourism Industry: Focus on Coastal Resorts in Kenya, Athens Journal of Tourism 
Mody, M. (2001) A model for integrated Sustainable Tourism Development in Developing Countries (e-book), http;//scholarworks.umass.edu

Mustafa. M. (2010) //Tourism and Globalization in the Arab World (e-book), http:/www.eis.hu.edu.jo (2-12-2013)

Kumar et al, (2015), Contribution of Public and Private Sector in Promoting State Tourism: A Case Study of Gujarat, Acme Intellects International Journal of Research in Management, Social Sciences \& Technology ISSN 2320 - 2939 (Print) 2320-2793 (Online), An Ultimate search of Truth- Reforms through Research Vol- 12 No. 12 Oct 2015

Ministry of Tourism, Sultanate of Oman websites (2000-20018).http://www.omaninfo.com/oman/business

Rummani, M. (2010) Sustainable Tourism.http://www.alukah.net/Home

Richard, G and Suntikul, D (2013) Tourism sector Realities http://www.goodfellowpublishers.com

Rajiha ,H, (2010) Promoting Tourism in Abu Dhabi using Social Media Master's Thesis in Media Technology, Royal Institute of Technology School of Computer Science and Communication KTH CSC SE-100 44 Stockholm, Sweden URL: $\underline{\text { www.kth.se/csc }}$

Salehi. H (2014), Tourism Advertisement Management and effective tools in Tourism Industry, International Journal of Geography and Geology, 2014, 3(10): 124-134

Sambhanthan. A (2013), Strategic Advantage in Web Tourism Promotion: An e-Commerce Strategy for Developing Countries,https:arxiv.org/ftp/arxiv/papers/1302/1302.5195.pdf

Tareeq and Salem (2009), Original Interaction between tourism and environment:http://www.mracpc.uobaghdad.edu.iq/uploads/magazine (Accessed: 8-11-2013) 